\title{
PENERAPAN PELAYANAN ASUHAN KEBIDANAN BAYI BALITA DI PRAKTIK BIDAN MANDIRI (PMB) PADA MASA PANDEMI COVID-19
}

\author{
Maya Indriati ${ }^{1}, \operatorname{Rosita}^{2}$ \\ ${ }^{1,2}$ Program Studi Diploma Tiga Kebidanan STIKes Dharma Husada Bandung \\ primaji0210@gmail.com ; rositasdhb@gmail.com
}

\begin{abstract}
COVID-19 has been declared a world pandemic by WHO in 2020. The government has the responsibility to ensure every citizen, including children, to obtain basic health services. At the Posyandu level, $86 \%$ of health facilities reported cessation of development and growth monitoring, $55 \%$ reported cessation of immunization services and $46 \%$ reported cessation of vitamin delivery services, and $46 \%$ cessation of antenatal care services.

This research used descriptive qualitative research method, by involving 2 midwives in independent midwife (PBM) and 2 parents who have babies and toddlers who got services at the independent midwife (PBM). During this pandemic, independent midwife (PBM) is still providing services as usual and there are no health protocols that must be carried out by service recipients during their visit. The number of visits showed a decrease, due to restrictions on visits for babies who did not have serious problems and needed action. There are factors that become obstacles in implementing services for infants and toddlers during this pandemic such as parental knowledge is lacking, there has been no socialization about services during the pandemic, and parents are afraid to come to the service. Supporting factors for the implementation of services obtained several important themes, including the support of health workers, and the importance of examining babies and toddlers independently at home.

It is hoped that parents who have babies and toddlers will continue to monitor the health of their babies and toddlers even at home by looking for various information either from the media or being able to consult with health workers.
\end{abstract}

Keywords: Infant Service; The Covid-19 Pandemic.

\section{PENDAHULUAN}

COVID-19 telah dinyatakan sebagai pandemi dunia oleh WHO (WHO,2020). Dan juga telah dinyatakan Kepala Badan nasional penanggulangan Bencana melalui Keputusan nomor 9 A Tahun 2020 diperpanjang melalui Keputusan nomor 13 A tahun 2020 sebagai Status Keadaan Tertentu Darurat Bencana Wabah Penyakit Akibat Virus Corona di Indonesia. Selanjutnya dikarenakan peningkatan kasus dan meluas antar wilayah, Pemerintah menerbitkan Peraturan Pemerintah nomor 21 tahun 2020 tentang Pembatasan
Nasional Berskala Besar dalam Rangka percepatan Penanganan Corona Virus Disease 2019 (COVID-19), dan Keputusan Presiden no 11 tahun 2020 yang menetapkan Status Kedaruratan Kesehatan Masyarakat, kemudian diperbaharui dengan Keputusan Presiden No. 12 tahun 2020 tentang Penetapan Bencana non alam penyebaran COVID-19 sebagai Bencana Nasional. ${ }^{1}$

Seiiring dinyatakannya COVID-19 sebagai pandemi oleh Organisasi Kesehatan dunia (World Health Organization/WHO) pada awal Maret 2020 dan penetapan bencana nasional, 
Pemerintah Republik Indonesia segera menindak-lanjuti dengan kebijakan untuk mencegah penyebaran virus. Hal ini mencakup intervensi-intervensi batasan fisik, seperti Pembatasan Sosial Berskala Besar (PSBB), pengurangan nyata untuk perjalanan internasional dan domestic, larangan berkumpul, serta penutupan sekolah, pabrik, restoran dan tempat-tempat umum. Aturanaturan tersebut berdampak pada layanan kesehatan. Untuk lebih memahami besaran layanan yang terhenti, Kementerian Kesehatan dan UNICEF melakukan kajian terhadap kelangsungan layanan ibu dan anak di fasilitas kesehatan. $^{2}$

Di sisi lain, Pemerintah mempunyai tanggung jawab untuk menjamin setiap warga negara termasuk anak untuk memperoleh pelayanan kesehatan dasar yang tertuang dalam Peraturan Pemerintah no 2 tahun 2018 tentang Standar Pelayanan Minimal dan Peraturan Menteri Kesehatan nomor 4 tahun 2019 tentang Standar Teknis Pemenuhan Mutu Pelayanan Dasar Pada Standar Pelayanan Minimal Bidang Kesehatan. Pelayanan Kesehatan Balita didalamnya meliputi pemantauan pertumbuhan, perkembangan, pemberian imunisasi dasar dan lanjutan, kapsul vitamin A dan tatalaksana balita sakit jika diperlukan. ${ }^{1}$

Dalam masa penyebaran COVID-19, tenaga kesehatan yang terkait sasaran balita, memiliki peran antara lain: (1) Melakukan koordinasi lintas program di Puskesmas/fasilitas kesehatan dalam menentukan langkah-langkah menghadapi pandemi COVID-19. (2)
Melakukan sosialisasi terintegrasi dengan lintas program lain termasuk kepada masyarakat yang memiliki balita, tentang pencegahan penyebaran COVID-19, kondisi Gawat Darurat dan informasi RS rujukan terdekat. (3) Melakukan analisa data balita berisiko yang memerlukan tindak lanjut. (4)Melakukan koordinasi kader, RT/RW/kepala desa/kelurahan, dan tokoh masyarakat terkait sasaran anak dan pelayanan kesehatan rutin dalam situasi pandemi COVID-19. (5 )Memberikan pelayanan kesehatan kepada balita dengan melakukan triase, penerapan prinsip Pencegahan dan Pengendalian Infeksi (PPI) dan jarak fisik (physical distancing) dalam pelayanan kesehatan yang diberikan. ${ }^{1}$

Tenaga kesehatan melaporkan terhentinya layanan di tingkat masyakarat, yang mana lebih dari $75 \%$ posyandu yang tutup dan lebih dari $41 \%$ kunjungan rumah terhenti. Fasilitas kesehatan primer (Puskesmas) melaporkan lebih sedikit layanan yang terhenti, yaitu kurang dari 10 persen, dimana hasil serupa juga terlihat pada zona-zona PSBB. Pada tingkat posyandu, $86 \%$ fasilitas kesehatan melaporkan terhentinya pemantauan perkembangan dan pertumbuhan, $55 \%$ melaporkan terhentinya layanan imunisasi dan 46 persen melaporkan terhentinya layanan pemberian Vitamin, serta $46 \%$ terhentinya layanan antenatal care (ANC). Hasil serupa juga terlihat pada terhentinya layanan tingkat posyandu di zona-zona PSBB dimana layanan terhenti pada daerah zona PSBB yang berkisar antara 74 sampai 81 persen. Pada tingkat 
puskesmas, layanan kesehatan melaporkan terganggunya beberapa layanan, yaitu layanan Keluarga Berencana (KB), imunisasi, MTBS, dan layanan pencegahan HIV yaitu PMTCT, serta layanan rutin kesehatan ibu dan anak. ${ }^{3}$

\section{METODE PELAKSANAAN}

Penelitian ini menggunakan metode kualitatif deskriftif, hal ini bertujuan untuk mengetahui secara cermat penerapan pelayanan pada bayi dan balita dengan metode indepth interview, terdapat 2 kelompok yang terdiri dari 2 orang petugas kesehatan sebagai bidan pelaksana, dan 2 orang tua yang mempunyai bayi balita yang sering melakukan pemeriksaan. Penelitian dilakukan pada bulan september februari 2021 di Praktik Bidan Mandiri di Wilayah Puskesmas Jayamekar Padalarang Kabupaten Bandung Barat.

\section{HASIL PENELITIAN}

Dalam implementasi penerapan pelayanan asuhan kebidanan bayi didapatkan beberapa tema penting diantaranya kualitas dan kuantitas asuhan kebidanan bayi bahwa selama pandemi ini PMB masih melakukan pelayanan seperti biasa dan tidak ada beberapa protokol kesehatan yang harus dilakukan oleh penerima layanan selama melakukan kunjungan. Sedangkan pada tema kuantitas bahwa kunjungan bayi dan balita menurun karena situasi PSBB yang membatasi masyarakat untuk melakukan aktivitas di luar rumah, mereka masih bisa melakukan konsultasi kesehatan dengan bidannya sehingga orang tua masih bisa memantau bayinya di rumah. Hal ini membuat para orang tua tidak telalu kawatir karena secara komunikasi mereka terhubung dengan baik, jika bayinya mengalami sakit dan memerlukan penanganan maka orang tua bisa datang dengan menerapkan protokol kesehatan. Dan orang tua juga merasa tenang ke tempat pelayanan karena di PMB sudah menerapkan protokol kesehatan.

Faktor penghambat didapatkan beberapa tema penting diantaranya kurangnya pengetahuan, kurangnya sosialisasi pelayanan, dan adanya rasa takut orang tua untuk datang ke tempat pelayanan. Sedangkan untuk faktor pendunung penerapan pelayanan asuhan kebidanan pada bayi dan balita dukungan tenaga kesehatan, dan pentingnya pemeriksaan bagi bayi dan balita secara mandiri di rumah selama pandemi covid-19, pentingnya pemeriksaan dan pemantauan bayi dan balita walaupun harus dilakukan mandiri dirumah. Hal ini sebenarnya sudah di sosialisasikan oleh petugas kesehatan agar orang tua dapat meminimalkan aktivitasnya di luar rumah kecuali bayi dan balita tersebut sakit dan memerlukan penanganan segera.

\section{PEMBAHASAN}

Pemerintah melalui Sistem Kesehatan Nasional, berupaya menyelenggarakan kesehatan yang bersifat menyeluruh, terpadu, merata, dan dapat diterima serta terjangkau oleh seluruh lapisan masyarakat. Upaya tersebut diselenggarakan dengan menitik beratkan pada pelayanan kesehatan untuk masyarakat luas, guna mencapai derajat kesehatan yang optimal. Salah satu upaya 
kesehatan adalah pemberian pelayanan kesehatan yang dilakukan bidan. masyarakat sangat memerlukan pelayanan kesehatan untuk menunjang tercapainya hidup sehat. ${ }^{9}$

Dalam rangka mewujudkan status kesehatan masyarakat yang optimal, maka berbagai upaya harus dilaksanakan, salah satu di antaranya ialah menyelenggarakan pelayanan kesehatan. Pandemi Covid-19 ini mengakibatkan perubahan pada pelayanan kesehatan yang dilakukan di tiap lini tempat pelayanan kesehatan. ${ }^{10}$

Akses keterjangkauan dan mutu pelayanan kesehatan memberi pengaruh yang besar terhadap keberhasilan pelaksanaan pembangunan bidang kesehatan itu sendiri. Dimana Indonesia merupakan wilayah dengan kondisi geografis yang cukup kompleks serta masih adanya ketimpangan sebaran fasilitas kesehatan, sehingga akses ke pelayanan kesehatan masih menjadi tugas penting untuk diselesaikan bersama agar seluruh masyarakat merasakan manfaat yang adil dan merata. ${ }^{9}$

Demikian juga akses pelayanan kesehatan untuk kelompok balita menjadi perhatian karena kesinambungan hidup pada kelompok tersebut menjadi salah satu tolok ukur pembangunan kesehatan. Diberlakukannya JKN dan pencapaian target UHC pada tahun 2019, menuntut adanya peningkatan akses dan mutu pelayanan kesehatan di fasilitas kesehatan. ${ }^{11}$

Keberlanjutan pelayanan kesehatan pada bayi dan balita di tengah pendemi COVID-19 tetap harus dilakukan sebagai upaya menurunkan Angka Kematian dan kesakitan bayi dan balita. Diperlukan pendekatan yang berbeda untuk mengupayakan kelangsungan pelayanan kesehatan anak yakni bersinergi dengan seluruh pihak baik lintas program dan juga lintas sektor. Setiap sektor mengupayakan pencegahan penularan COVID-19 pada kelompok usia bayi balita, memenuhi pelayanan kesehatan esensial dan mengupayakan perlindungan anak. Dalam rangka penanganan cepat COVID-19 telah diterbitkan Panduan Pelayanan Kesehatan Balita pada Masa Pandemi COVID-19 bagi Tenaga Kesehatan. ${ }^{12}$

Menghadapi masa pandemi COVID-19, masyarakat diharuskan untuk disiplin menghindari keluar rumah, menjaga jarak fisik dengan orang lain, memakai masker dan menerapkan perilaku hidup bersih sehat. Dalam rangka mencegah penularan COVID-19 pada balita dan anak pra sekolah, Puskesmas untuk mengidentifikasi keluarga dan institusi yang memiliki anggota balita dan usia pra sekolah seperti Panti/LKSA, PAUD/TK/RA untuk diberikan sosialisasi. ${ }^{10,11}$

Sosialisasi upaya pencegahan penularan COVID-19 pada balita dan anak pra sekolah juga diiringi cara menjaga kesehatan anak. Dalam hal ini, tenaga kesehatan harus memberikan nomor telepon atau kanal informasi yang siap dihubungi masyarakat untuk tele konsultasi atau janji temu jika anak memerlukan pemantauan atau pelayanan lebih lanjut. Tenaga kesehatan mengkoordinasikan hal-hal terkait upaya pencegahan penyebaran COVID-19 dan pemantauan kesehatan balita dan anak pra sekolah kepada kader kesehatan 
untuk membantu memperluas sosialisasi kepada masyarakat, pemantauan wilayah setempat diantaranya dengan memberikan umpan balik jika menemukan anak yang memerlukan pemantauan dan penanganan tenaga kesehatan. ${ }^{12}$

Tanda dan gejala COVID-19 pada anak sulit dibedakan dari penyakit saluran pernapasan akibat penyebab lainnya. Gejala dapat berupa batuk pilek seperti penyakit common cold atau selesma, dengan atau tanpa demam, yang umumnya bersifat ringan dan akan sembuh sendiri. Penyakit saluran pernapasan menjadi berbahaya apabila menyerang paru-paru, yaitu menjadi radang paru atau yang disebut pneumonia. Gejala pneumonia adalah demam, batuk, dan kesulitan bernapas yang ditandai dengan napas cepat dan sesak napas.

Biasanya gejala pada anak ringan sehingga memiliki kemungkinan sebagai carrier, namun data COVID-19 diatas menunjukkan persentase meninggal cukup tinggi, untuk itu sangat penting mencegah penularan pada kelompok usia balita, selain mencegah risiko kematian pada bayi dan anak balita juga mencegah risiko penularan kepada pengasuh atau orang disekitarnya. ${ }^{13}$

Adapun cara menjaga kesehatan anak secara mandiri di rumah yaitu tenaga kesehatan mengkoordinasikan kepada Kader Kesehatan untuk membantu memperluas sosialisasi kepada masyarakat dan memberikan umpan balik jika ditemukan anak perlu mendapat pemantauan lebih lanjut. Tenaga kesehatan memberikan nomor teleponnya atau nomor Jurnal Penelitian Kesehatan STIKes Dharma Husada Bandung fasilitas kesehatan yang dapat dihubungi untuk tele konsultasi atau janji temu jika anak memerlukan pemantauan atau pelayanan lebih lanjut. $^{13}$

\section{KESIMPULAN DAN SARAN}

Dalam implementasi pelayanan terdapat penurunan kunjungan bayi dan balita ke PMB, namun secara kualitas pelayanan masih tetap sesuai. Terdapat faktor penghambat dalam pelayanan pada bayi dan balita di masa pandemi covid-19 yaitu pengetahuan, belum adanya sosialisasi mengenai pelayanan di masa pandemi, dan rasa takut orang tua untuk datang ke tempat pelayanan. Terdapat faktor pendukung dalam pelayanan pada bayi dan balita di masa pandemi covid-19 yaitu dukungan tenaga kesehatan dan pentingnya pemeriksaan dan pemantauan bayi dan balita.

Diaharapkan kepada para orang tua yang memiliki bayi dan balita tetap memantau kesehatan bayi dan balitanya walaupun dirumah dengan mencari berbagai informasi baik dari media ataupun bisa berkonsultasi dengan petugas kesehatan.

\section{DAFTAR PUSTAKA}

1. Kementerian Kesehatan RI direktorat jenderal Kesehatan masyarakat direktorat Kesehatan keluarga. 2020. Panduan pelayanana Kesehatan Balita Pada Masa Pandemic Covid-19. 2020.

2. UNICEF and Ministry of Health RI. Rapid Asessment: Impact of COVID-19 Pandemic on Immunization Services in Indonesia, 
JURNAL SEHAT MASADA VOLUME XV

UNICEF and MoH-RI Direktorat Surveilans dan Karantina Kesehatan; 2020.

3. Ministry of Health RI. Pedoman Bagi Ibu Hamil, Ibu Nifas dan Bayi Baru Lahir Selama Social Distancing, MoH-RI Direktorat Jendral Kesehatan Masyarakat, Direktorat Kesehatan Keluarga; 2020.

4. World Health Organization, Indonesia. COVID-19 Situation Report, Vol. 2019, 2020.

5. Pedoman Pencegahan dan Pengendalian Coronavirus Disease (COVID-19) Revisi ke-4

6. Gugus Tugas Percepatan Penanganan COVID-19. 2020. Pedoman Penanganan Cepat Medis dan Kesehatan Masyarakat COVID-19 di Indonesia.

7. Kementerian Kesehatan RI. 2019. Buku Kesehatan Ibu dan Anak.

8. Pedoman Manajemen Terpadu Balita Sakit (http://kesga.kemkes.go.id/
images/pedoman/BUKU\%20KIA\%202019. pdf)

9. Pedoman pelayanan terpadu Ibu Hamil dan Balita dalam pengendalian Malaria di Fasyankes

10.Keputusan Menteri Kesehatan RI Nomor HK.01.07/MENKES/556/2019 tentang Pedoman Nasional Pelayanan Kedokteran Tata Laksana Malaria

11.Surat Edaran Dirjen Direktur Jenderal P2P Nomor SR.02.06/4/1332/2020 tanggal 24 Maret 2020 tentang Pelayanan Imunisasi Pada Anak selama masa Pandemi Corona Virus Disease 2019

12.Panduan Ikatan Dokter Anak Indonesia Mengenai COVID-19

13.Panduan Pelayanan Kesehatan Balita pada Masa Pandemi COVID-19 bagi Tenaga Kesehatan 